\title{
Effects Of Exchange Rate Volatility On Real Estate Prices In Developing Economies, A Case Of Ghana
}

\author{
John Kwame Adu Jack \\ Finance Lecturer; \\ Business School, KAAF University College \\ Frimpong Okyere \\ Finance Lecturer; \\ Business School , KAAF University College \\ Emmanuel K. S. Amoah \\ Accounting Lecturer; \\ Business School , KAAF University College
}

\begin{abstract}
This study aims to find out whether exchange rate volatility affects real estate domestic house prices in Ghana. To this end, a 32 years secondary data from World Development Indicators (WDI) and data from Real Estate Developers in Ghana are employed for the study. The study employs Autoregressive distributed lags (ARDL) bounds testing of cointegration to test the null hypothesis that exchange rate volatility has no impact on real estate housing prices. The study finds that real estate price is cointegrated with remittances, exchange rate and inflation. The long run equilibrium is stable and significant. Exchange rates do not cause changes in real estate prices in both short and long run. Similarly past prices of real estate do not have impact on current house prices. Rather, remittances positively cause real estate prices. Inflationon its part has a negative impact on real estate prices. It is therefore concluded that, volatility in the exchange rate between the cedi and other trading currencies does not predict changes in real estate prices.
\end{abstract}

Key words: Exchange Rate Volatility; Real Estate Prices; Inflation; Remittances; World Development Indicators (WDI); GREDA.

\section{INTRODUCTION AND RESEARCH OBJECTIVES}

The relationship between real estate prices and foreign exchange rate has always been an important issue mainly because of the concern about the perceived impact of foreign exchange rate fluctuation on prices of general goods and services in import driven economies. There are various arguments that have evolved in relation to how a fluctuating foreign exchange rates can have substantial impact on the performance and profitability of domestic businesses and on real estate house prices and potential house owners' incomes.

The rapidly globalization agenda in trade and the adoption of floating or managed exchange rates by many developing countries or emerging economies are the recipe to the new era of increased foreign exchange volatility (Jorion, 1990). For the investor, changes in exchange rate poses a foreign exchange risk. High fluctuations in exchange rates can lead to huge losses in an investor's portfolio of investments due to uncertainty of return on investments. This is due to the fact that movements in foreign exchange rates affect the prices of goods on the local and international markets thereby affecting real estate prices in developing economies. 
The exposure of firms to foreign exchange rate risks has increased as a result of overly dependent on importation (Murinde, 1993). Two different types of risks under an independently floating exchange rate regime are identified in the existing literature. Transaction exposure arises due to gains or losses arising from settlement of investment transactions stated in foreign currency terms.

\section{Statement of the Problem}

Although, Fiadzo, (2004); CHF International, (2004); Hammond, (2006); Buckley and Mathema, (2007) dedicate some studies on the general housing situation in Ghana, they argue that, residential investment market, shockingly, receives little recognition. Albeit, there is considerable evidence available on formal residential real estate transactions - sales and lettings. However, few previous works quantitatively examine the performance of this market, vis-à-vis the FOREX rates of the Ghanaian currency for the fact that most investors in real estate market are foreign nationals and Ghanaians living abroad. It is upon this premise that, it is imperative to study how fluctuating exchange rates affect residential house prices in Ghana (Jurion, 1990).

Apparently, when currencies fluctuate uncontrollably, they should influence both local and foreign prices of real estate houses such as residential houses and commercial houses (Omolara, 2010; Jurion, 1990). It is upon this that it is important to ascertain its effect on domestic real estate house prices since it is a fact that, Ghana is an import driven economy where almost everything including toothpick is imported, and that prices of such imported items are dependent hugely on the foreign exchange rate. Whatever affects the prices of imported raw materials automatically affects property development such as real estate residential house prices. There is no doubt that Ghana's foreign exchange market is bedeviled with high volatility, and that it is important to find out how this fluctuation of the Ghana Cedi (GHC) to the United States Dollar (U.S.\$) affects residential real estate house prices in Ghana (Oluwe, 2009). Again, Diala, Kalu and Igwe-Kalu (2016) posit that property market in emerging economies need to offer diversification benefit to international investors which precipitate the study of how exchange rate movement affects commercial and residential real estate prices. Ghana government estimates the housing shortfall to be over 1.6 million housing units. This indicates that housing deficit is a big challenge to Ghana and as a result, various attempts are made by various governments to provide affordable housing to fix the problem. Arguably, fixing the problem requires more imports of building materials, since Ghana is an import driven economy which, undoubtedly requires high demand for foreign currencies.

However, no empirical work is done in Ghana to test the effect or impact of the volatile nature of the local currency, the Cedi against the major foreign currencies especially the U.S. Dollars on real estate housing prices. The real estate companies in Ghana are also increasing in numbers and therefore there is the need to have scientific and empirical studies to inform investors and industry players of the variables to look out for when venturing into the real estate market in Ghana.

Various researchers including Alagidede and Ibrahim, (2016) posit that, exchange rate volatility affects general prices of goods and properties. However, empirical evidence by Diala, Kalu \& Igwe-Kalu (2016) suggests that exchange rate volatility has little impact on commercial property investment returns which triggers the need for this study to examine how the volatility of exchange rate impacts on real estate house prices in Ghana.

\section{Research Objectives}

The general objective of this study is to find out how changes or fluctuations of the Ghanaian currency against major trading currencies, especially the U. S. Dollar, affect housing pricing in 
Ghana. Specifically the study is to: Analyze the relationship between exchange rates and housing prices in Ghana and also identify other macroeconomic factors that affect housing prices.

\section{Significance of the Study}

After successful completion of this study, the findings will help investors in taking decisions in the era of floating exchange rate regime adopted in Ghana when investing in real estate housing market. It will also augment the existing store of knowledge on the subject and will serve as a catalyst for further research on other variables and how they affect housing pricing in Ghana. The study will establish the relationship between exchange rate volatility and the pricing of real estate residential houses in Ghana. It will examine how the housing market responds to variations in foreign exchange rates and this will also help the government to come out with policies to regulate the housing market.

\section{Scope of the Study}

The scope of the study is to provide a realistic insight into the trends in exchange rate and housing prices. It includes remittances and inflation. The study focuses on the exchange rate and housing prices from 1986 to 2017. The data for this research is limited to real estate firms such as Dannywise Real Estate Developers, Real Estate Developers Association of Ghana (GREDA) and data from WDI Database.

\section{THEORITICAL LITERATURE}

Exchange rate volatility which is defined as the persistent swinging of the exchange rate takes center stage in recent literature in international finance due to its effects on developing economies. Exchange rate swinging is the bane of concern in both developed and developing economies in an astonishing manner due to inflation, investment and more generally economic activities (Danjuma et al., 2013; Kiyota and Urata, 2004;Fuentes, 2006; Adewuyi and Akpokodje, 2013).

The theoretical literature on the effect of exchange rate volatility on the economy is still a matter of great debate among economist. The theoretical work by Obstfeld and Rogoff's (1995) reveals that exchange rate volatility is surely expensive to the local economy through both direct and indirect effects on households and firms respectively. The direct effects are based on the fact that households are not enthused about exchange rate movements because of the difficulty in consumption flexibility as well as fluctuations in leisure consumption. The indirect effect on the other hand assumes that trying to hedge exchange rate risk, firms usually set higher prices in the form of risk premium which may have dire consequence on general price stability. Agreeably exchange rate volatility has been identified to reduce the level of economic growth by creating business uncertainty, deteriorates competitiveness, lower productivity and profits and hence increasing domestic prices (Eichengreen, 2008). This clearly has investment, welfare, economics, etc implications and should be a policy concern.

Real estate is a highly unrelated good that is conducted in markets with extremely complex intertwined high transaction costs. Issues related to Liquidity and government manipulation in the markets further introduce complexities in the observation of general price changes. The struggle in observing the genuine price movements of real estate markets is a basic concern that supports the construction of real estate price index.

According to Omolara (2010), exchange rates constitute the price of one currency in terms of another. The opinion of Jurion (1990) is that a volatile exchange rate raises strategic and managerial issue because it leads to losses or gains. As far as currency swinging can have effect 
on both local and foreign prices of goods, it is then important to determine its effects on real estate residential prices since whatever affects the prices of imported raw materials affects property prices. Ghanaian foreign exchange market is too volatile and that there is the need to determine how this volatility of exchange rate affects residential real estate house prices in Ghana (Olowe, 2009).

Exchange rates volatility as a result of the introductionof floating regimes occasion tremendous recognition in economic research (Senadza and Diaba, 2017). They posit that the exchange rate fluctuation is generally perceived as negatively impacting international trade. Their position is partially supported by international trade theory which indicates that depreciation of local currency to the foreign trading partners currency inures to the benefit of the local economy and vice versa on condition that the local economy is not import dependant and as such will positively affect Balance of Trade. While theoretical predictions and empirical outcomes appear mixed, the balance seems to tilt in favour of this perception.

Erratic movements in exchange rate have raised renewed interest to the perceived negative effects on international trade (Dell' Ariccia, 1999). It is instructive to understand that the adverse effect of exchange rate volatility in many Sub-Saharan Africa(SSA) economies is associated to import dependency syndrome. The effect of this syndrome is that ideally the high volatility affects the prices of imported commodities which scientifically affects prices of real estate housing, because, most of the building materials are imported. The traditional school of thought holds the same view that by increasing the risk associated with cross-border activities, volatilities in exchange rates may dampen the volume of international trade, because traders who are risk-averse may replace their high-risk trading activities towards less risky ones (McKenzie, 1999).

\section{Empirical Literature Review}

On the Sub-Saharan Africa (SSA) scene, only few studies are carried out in relation to the exchange rate volatility on trade and its embedded activities. Osei-Assibey, (2010) analyses the impacts of exchange rate volatility on trade flows in Ghana, Mozambique and Tanzania economies in respect to their trading partners, where volatility proxies are generated using the generalized autoregressive conditional heteroskedasticity (GARCH) model. With a gravity specification, it finds that the effect of volatility on trade earnings is insignificant. In like manner, Akpoodje and Omojimite, (2010) examine the effect of exchange rate volatility on the imports of ECOWAS countries using the GARCH model in generating the volatility series. It shows a significant negative effect of exchange rate volatility on imports in the pooled model consisting of all the ECOWAS economies. However, the results of the sub-group of countries are mixed. Whereas the non-CFA sub-group proves a negative correlation, the CFA sub-group shows positive volatility coefficients. The seemingly mixed results from empirical studies, while suggesting that the effect of exchange rate volatility on trade might be an empirical issue, may also reflect the emptiness of theoretical results in the general equilibrium models; they allude to the fact that inconsistency in exchange rates is contingent on the volatility of underlying shocks to policies, preferences, and technology, to the overall policy regime (Clark et al., 2004). Meaning, exchange rate swings may be as a result of simply the changes in the volatility of rudimentary shocks propagated by the Driskill-McCafferty model (Grydaki and Fountas, 2009).

The frequency of volatility and instability of the exchange rate movement since the fall of Britton Wood exchange rate regime and the adoption of the floating exchange rate raises concern about the impact of such movements on construction materials and residential real estate house prices and investment returns (Olowe, 2009). Joseph and Akhanolu (2011) posit 
that many international economics analysts agree that the generalized floating of exchange rate system that has characterized the international trading space since the post Bretton Wood period have engendered unreasonable volatility in both developed and developing economies. The proponents of fixed exchange rate according to Alagidede and Ibrahim (2016) argue that flexible exchange rate increases uncertainty in trade which resorts to reduction in trade volumes since it exposes importers to greater risks due to the fluctuations.

Whilst using GARCH model to deal with exchange rate management, Mordi (2006) opined that failure to properly manage exchange rates can create distortions and risks with devastating effect on every economy. This assertion is concurred by Attela, Atzeni and Belvisi (2003) who finds out that exchange rate volatility determines the instability of expected profit, but the degree and the consequence of their relationship remain an empirical question. Upon these assertions that Lee and Thomas (2006) test the impact of exchange rates on international real estate portfolio allocation and conclude that currency instability changes the gains from diversification related to real estate investment. Indicatively, Liu and Mei (1998) confirm that diversification benefits are found to be fundamentally controlled by unexpected returns which are partially controlled by changes in exchange rate risk. Since international real estate investment is very crucial in the real estate portfolio construction process, investing in international property markets calls for conversion of domestic currency to that of the foreign country. Therefore, the determination of the effects of currency fluctuations on property returns is of prime importance (Webb and O'Keefe, 2002).

Bank of Ghana in 2007 studies the housing market in Ghana. Empirical evidence on the housing sector suggests that governments that pursue housing policies based on the "enabling markets approach" have better results than those that pursue traditional policies based on direct public sector supply and financing of houses for low-income families. This 'enabling markets approach' relies on the private sector as the main supplier of houses and issuer of long-term financing for households of all income levels, with the government playing a role as regulator and facilitator of housing markets. The approach minimizes the direct influence of government in direct construction and financing of houses, and rather promotes government interventions on the development of private housing financing, the facilitation of land subdivision for residential uses, the improvement of the construction industry and the support of affordable housing solutions for low-income households.

Balaban (2011) studies how migrant remittances and resulting transformation affect housing market in Romania. The research uses a mixed method approach consisting of qualitative and quantitative methods. The study establishes that there is a direct relationship between migrant remittances, resulting transformation on one side and housing market in Romania on the other side.

Lim and Tsiaplias (2016) investigate the effect of interest rates on regional house price in Australian and US using vector autoregression model (VAR). The results provide evidence that house price to income ratios depends non-linearly on interest rates, and moreover that there is an interest rate 'transition point' below which a house price bubble is probable. They also investigated the implications of monetary policy of stable and unstable house price regimes and propose a housing lending rate lower bound that achieves long-run house price stability in the presence of regime uncertainty. To check the generality of the result, they also apply the model to aggregate Australian and US data.

Loyford and Moronge (2014) study the effects of economic factors on performance of real estate in Kenya. Stratified sampling technique is used to select the sample from each stratum; 
the study uses simple random sampling giving the study a sample population of 44 respondents from the target population which is believed to be a good representation of real estate market. Primary data is gathered using semi-structured questionnaires where the respondents are issued with the questionnaires. The results conclude that, interest rate, inflation, transactions cost and demand for housing highly influence the performance of real estate industry. They settled that interest rate is stochastic in determining the performance of any property market. Therefore, the government is to take a stake in the real estate industry to balance macroeconomic effects particularly the interest rate and inflation that highly affects the industry's performance.

Fayissa and Nsiah, (2008) analyze the impact of remittances on economic growth and development from 1980 to 2004 for 37 African Countries. Ordinary least squares (OLS) model was used for the study. The result shows that on the average remittances have impacts on economic growth. According to them remittances boost growth in countries where the financial system are less developed by providing an alternative way to finance investment and help overcome liquidity constraints.

\section{RESEARCH METHODOLOGY}

The study is purely explanatory research. Explanatory studies establish causal relationships between variables (Saunders et al., 2007). This study seeks to investigate the relationship between the prices of residential real estate houses and fluctuations in exchange rates to detect significant interactions between the variables using numerical data. A thirty-two year annual data (1986 - 2017) is gathered from WDI and some Real Estate Developers including Dannywise and Ghana Real Estate Developers Association (GREDA).

The residential real estate used in the study includes semi-detached apartments, detached bungalows, duplexes and apartment blocks. However, the preliminary checks from the Real Estate Developers indicate that about $85 \%$ of their houses are the semi-detached apartments of three (3) bedrooms, a hall, kitchen and other compliments of a house. Upon this revelation, the study is focused on the semi-detached apartment.

To study interaction between prices of real estate houses and exchange rates, four variables namely real estate house prices, exchange rate, remittances and inflation is used.

Documentary data on exchange rate movements, rate of inflation, inflows of remittances are collected from the World Development Indicators (WDI) database website within the study period. On the part of real estate house prices, data is collected from GREDA and some real estate developers such as Dannywise. The reasons for choosing especially GREDA are that, it exists by Law under the Ghana's Company Code Act 179, of 1963, under Public Private Partnership (PPP) concept. Again, it has officially being in existence since 1988 and the members have in-depth knowledge of the industry and also the caliber of some of the persons who were initially appointed to steer the Association had being in the industry as building contractors for very long time before the official formation of the Association in 1988. The study focuses on 1986 - 2017 for many reasons among them includes the fact that there is the need to try and reflect on the pre-formation of GREDA. Therefore, 1986 is chosen because of unavailability of data on the other variables, i. e., independent variables before 1986 at the time of data surfing.

This study is limited to residential house property prices and exchange rate movement from 1986 to 2017 using Cedi/ US Dollar exchange rate. The strategy that is adopted in the data collection includes a combination of interviews and documentary data collection from WDI 
Database. The major focus of the interview is prices of real estate houses within the period covered by the study. The data gathered from the interview is a market based and has not been published.

\section{Model Specification \\ Model Specification}

The final model therefore takes the following form:

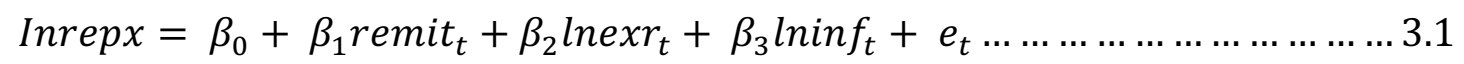

Where:

repx $=$ Real estate pricing

remit $=$ Remittances

lnexr $=$ Exchange Rates

$\operatorname{lninf}=$ Inflation

$\beta_{0} \ldots \ldots \beta_{3}=$ Represent the intercept and the regression coefficients (or elasticities) associated with their respective explanatory variables

$\ln =$ the natural $\log$ of the continuous variables described above

$e_{t}=$ error term

$t=$ time period in yearly

\section{Stationarity Test}

This is where the study estimates the parameters. In order to ensure the reliability of the estimates of the parameters of equation 3.1 using time series data, three steps are followed. First, each of the individual variables in our regressions model is examined for unit root to ensure that the estimated relationships are not spurious. In order to evaluate if the data are stationary or not, unit root test is required. This is to ensure that the variables are stationary and that shocks are only temporary and will dissipate and revert to their long-run mean..

It is important to test for unit root of the variables to determine the order of integration of each of the variables as is required for the use of time series data for analysis. The number of tests available for testing whether a series is stationary or not include the following; the Dickey- Fuller (DF) test, Augmented Dickey-Fuller (ADF) test, the KPSS test as well as the Phillips Perron (PP) test among others. This study applies the Augmented Dickey-Fuller Test (ADF) to check for stationarity following Augmented Dickey and Fuller (1981) and Fuller (1996). Since the Phillips-Perron (PP) test attempt finding a way of handling deviations in order not to achieve white noise in the estimated model, it was applied to confirm the results of the ADF test. The PP tests are based on the following ADF regression, and the critical values are the same as those used for the ADF tests following Phillips and Perron (1988). The equation below is employed:

$\Delta \mathrm{y}=\mathrm{b}_{1}+\mathrm{b}_{2} \mathrm{t}+\mathrm{b}_{3} \mathrm{y}_{\mathrm{t}-1}+\sum_{n=1}^{n}\left(B_{i} \Delta y_{t-i}\right)+\mathrm{u}_{\mathrm{t}}$

Where,

$\Delta$ is the difference operator,

$\mathrm{y}$ is the natural logarithm of the series,

$\mathrm{t}$ is a trend variable,

$b_{1}, b_{2}$ and $b_{3}$ are the parameters to be estimated,

$B$ is the vector of the estimated parameters of the lagged values of the differenced value of time series 
$\Delta y_{t-i}$ stands for the vector of the lagged value of the differenced value of the series and $\mathrm{u}$ is the error term.

Decisions as to whether the model is stationary or otherwise is based on the hypothesis below;

$\mathrm{H}_{0}: \mathrm{b}_{1}=\mathrm{b}_{2}=\mathrm{b}_{3}=0$

$\mathrm{H}_{1}: \mathrm{b}_{1} \neq \mathrm{b}_{2} \neq \mathrm{b}_{3} \neq 0$

Rejection of the null hypothesis denotes stationarity in the series. If we don't reject the null hypothesis, we conclude we have a unit root. So the ADF and the PP tests are run at level and first difference with trend and intercept.

\section{Estimation Techniques}

Many studies are done on this topic in various countries employing ordinary least square model in testing for the relationship between real estate pricing, housing pricing and selected macroeconomic variables. However, this study employs the ARDL to test for the long-run and short-run relationships between the selected variables. The study employs ARDL model for the following advantages which include; ARDL model is the more statistically significant approach to determine the co-integration relation even when the sample size is small. Also, the ARDL approach does not require all of the regress ors to be integrated of the same order unlike other co-integration techniques which requires that; the ARDL technique can be applied whether the regressors are I(1) and/or I(0). In effect, the ARDL technique avoids the pre-testing problems associated with standard co-integration, which requires that the variables are already classified into I(1) or I(0) (Pesaran et al, 2001). This model is even the more appropriate model for empirical work in a case where the unit root properties of the data are uncertain.

Actually, a number of time series studies have used the Johansen's cointegration technique to determine the long-run relationship between variables of interest. This method is said to be the most accurate when applying for I (1) variables and remains the choice for many researchers.

Meanwhile, Peseran and Peseran (1997), Peseran and Shin (1999), and Peseran et al. (2001) introduce an alternative co-integration tool known as the Autoregressive Distributed Lag (ARDL) bounds test.

This tool has a number of advantages over the Johansen's co-integration technique. It is widely accepted that, the ARDL Approach is the best statistical technique to determine the cointegration relationship in small sample size data (Ghatak \& Siddiki, 2001), as compared to the Johansen's co-integration technique which requires large data samples for validity. Again, where other tools require all the regressors to be integrated in-like manner of order, the ARDL approach can be applied whether the regress ors are I (1) or I (0). It therefore implies that, the ARDL approach avoids the pre-testing problems associated with standard co-integration, which demands that the variables are either I (1) or I (0) (Peseran et al., 2001). Furtherance to this position, Tang, (2006) states that, the ARDL approach is also applicable to endogenous explanatory variables which are also enough to simultaneously correct residual serial correlation. In any co-integration technique according to Bahmani-Oskooee and Kandil (2007), the first step is to determine the depth of integration of each variable in the model depending on which unit root test is applied since different unit root tests could lead to contradictory results. For instance, when applying the conventional unit root tests such as the Augmented Dickey-Fuller and the Philips-Perron tests, one may wrongly conclude that a unit root is present in a series that is actually stationary around one-time structural break (Perron, 1997). Hence, the ARDL approach is best used because it prevents all these problems. The other 
challenge of the Johansen's co-integration technique that the ARDL approach prevents has to do with the large number of choices which must be made including decisions regarding the number of endogenous and exogenous variables to be included in the model, the treatment of determinant elements, including the order of VAR and the optimal number of lags to be employed. Sufficing it all, with the application of the ARDL approach, it is possible to have different variables that have different optimal number of lags, while in Johansen's technique, this is not allowed.

Peseran and Peseran (1997) posit that, the ARDL approach demands the following two steps. First, the existence of any long-run relationship amongst the variables of interest is determined using an F-test. Secondly, the analysis is to estimate the coefficients of the long-run relationship and determine their values with the estimation of the short-run parameters of the variables and the error correction representation of the ARDL model. Thus, one needs to apply the error correction model (ECM) versionof ARDL to determine the speed of adjustment to equilibrium. In order to run the long run estimation, the Bounds test is first applied to check for long run relationship. Generally, the dynamic structure of the $A R D L(p, q)$ model takes the following form;

$\Delta \mathrm{X}_{\mathrm{t}}=\mathrm{a}_{0}+\mathrm{a}_{1} \mathrm{t}+\mathrm{a}_{2} \mathrm{X}_{\mathrm{t}}+\mathrm{a}_{3} \mathrm{Z}_{\mathrm{t}}+\sum^{\mathrm{p}_{\mathrm{i}=1}} \mathrm{~A}_{\mathrm{i}} \mathrm{X}_{\mathrm{t}-\mathrm{i}}+\sum^{\mathrm{q}_{\mathrm{j}=0}} \mathrm{~B}_{\mathrm{j}} \mathrm{Z}_{\mathrm{t}-\mathrm{j}}+\mu_{\mathrm{t}}$

$\mathrm{H}_{0}: \mathrm{a}_{2}=\mathrm{a}_{3}=0$

$\mathrm{H}_{1}: \mathrm{a}_{2} \neq \mathrm{a}_{3} \neq 0$

The hypotheses stated above can be determined through the use of the standard F-statistic. When the null hypothesis is rejected, it means there is co-integration among variables otherwise there is no co-integration among the variables.

In the application of the bounds test to cointegration, the real estate prices and its underlying variables are modeled as conditional ARDL $\left(p, q_{1}, q_{2}, q_{3}\right)$

$$
\begin{aligned}
& \Delta \text { lnrepx }_{t}=\gamma_{01}+\rho_{11} \text { lnrepx }_{t-1}+\rho_{21} \text { lnremit }_{t-1}+\rho_{31} \text { nnexr }_{t-1}+\rho_{41} \operatorname{lninf}_{t-1} \\
& +\sum_{i=1}^{p} \gamma_{1 i} \Delta \text { lnrepx }_{t-i}+\sum_{i=1}^{p} \gamma_{2 i} \Delta \text { lnremit }_{t-i}+\sum_{i=1}^{p} \gamma_{3 i} \Delta \text { lnexr }_{t-i}
\end{aligned}
$$

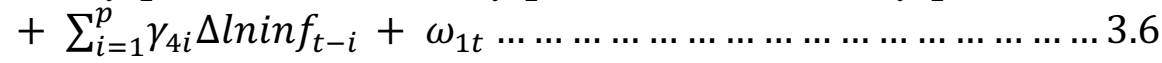

We test the hypothesis that:

$$
\begin{aligned}
& H_{0}: \rho_{1 i}=\rho_{2 i}=\rho_{3 i}=\rho_{4 i}=0 \\
& H_{1}: \rho_{1 i} \neq \rho_{2 i} \neq \rho_{3 i} \neq \rho_{4 i} \neq 0
\end{aligned}
$$

Where $i=1,2,3$,

Given a smaller sample size the ARDL error correction will be performed pursuant to a confirmation of cointegration equation an Error Correction Model (ECM) is specified as this

$$
\begin{aligned}
\Delta \text { lnrepx }_{t}= & \gamma_{01}+\sum_{i=1}^{p} \gamma_{1 i} \Delta \text { lnrep }_{t-i}+\sum_{i=1}^{p} \gamma_{2 i} \Delta \text { lnremit }_{t-i}+\sum_{i=1}^{p} \gamma_{3 i} \Delta \text { lnexr }_{t-i} \\
& +\sum_{i=1}^{p} \gamma_{4 i} \Delta \operatorname{lninf}_{t-i}+\phi E C T_{t-1}+\omega_{t} \ldots \ldots \ldots \ldots \ldots \ldots \ldots \ldots \ldots \ldots .3 .7
\end{aligned}
$$

Where $E C T_{t-1}$ is the error correction term with $\phi$ as the speed of adjustment parameter.

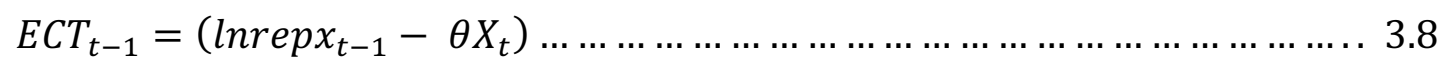


$\theta$ hich, the long run parameter is given by $\frac{\Sigma_{i=0}^{p} \beta_{i}}{\psi}$

$\phi$ is given $\left(1-\Sigma_{i=1}^{p} \delta_{i}\right)$

$\gamma_{1 i}, \gamma_{2 i}, \gamma_{3 i}, \gamma_{4 i}$ are the models adjustment to the long run equilibrium by the short run coefficient.

The long run model takes this form.

$$
\begin{gathered}
\operatorname{lnrepx}_{t}=\alpha_{01}+\sum_{i=1}^{p} \eta_{1 i} \operatorname{lnrepx}_{t-i}+\sum_{i=1}^{p} \eta_{2 i} \operatorname{lnremit}_{t-i}+\sum_{i=1}^{p} \eta_{3 i} \operatorname{lnexr}_{t-i}+\sum_{i=1}^{p} \eta_{4 i} \operatorname{lninf}_{t-i} \\
+\sigma_{t t} \ldots \ldots \ldots \ldots \ldots \ldots \ldots \ldots \ldots \ldots \ldots \ldots \ldots \ldots \ldots \ldots \ldots \ldots \ldots \ldots \ldots \ldots \ldots \ldots \ldots \ldots \ldots \ldots \ldots
\end{gathered}
$$

In the case of no cointegration, which indicates no long run relationship just the ARDL model is specified as below for the short run relationship and causality

$$
\begin{aligned}
\Delta \operatorname{lnrepx}_{\mathrm{t}}= & \gamma_{01}+\sum_{\mathrm{i}=1}^{\mathrm{p}} \gamma_{1 \mathrm{i}} \Delta \operatorname{lnrepx}_{\mathrm{t}-\mathrm{i}}+\sum_{\mathrm{i}=1}^{\mathrm{p}} \gamma_{2 \mathrm{i}} \Delta \operatorname{lnnemit}_{\mathrm{t}-\mathrm{i}}+\sum_{\mathrm{i}=1}^{\mathrm{p}} \gamma_{3 \mathrm{i}} \Delta \operatorname{lnexr}_{\mathrm{t}-\mathrm{i}} \\
& +\sum_{\mathrm{i}=1}^{\mathrm{p}} \gamma_{4 \mathrm{i}} \Delta \operatorname{lninf}_{\mathrm{t}-\mathrm{i}}+\omega_{\mathrm{tt}} \ldots \ldots \ldots \ldots \ldots \ldots \ldots \ldots \ldots \ldots \ldots \ldots \ldots \ldots \ldots \ldots \ldots \ldots \ldots \ldots \ldots \ldots \ldots \ldots \ldots \ldots \ldots \ldots \ldots \ldots \ldots \ldots \ldots
\end{aligned}
$$

\section{Diagnosis and Stability Tests}

In every research work, the results should be reliable for policy implementation. Hence diagnostic tests are done to examine the reliability of the results of the study. The study tested for the significance of the variables and other diagnostic tests such as serial correlation, functional form, normality; heteroskedasticity and structural stability of the model are carried out.

The Breusch-Pagan-Godfrey test for heteroskedasticity, Breusch-Godfrey Serial Correlation LM Test for serial correlation, the Jacque-Berra test for normality and also, the Ramsey RESET Test for stability were applied in the analysis of diagnostic and stability tests of the long-run coefficients together with the short-run dynamics. Following Pesaran and Pesaran (1997), the stability of the regression coefficients is evaluated by stability tests and they can show whether or not the regression equation is stable over time. This stability test is appropriate in time series data, especially when we are uncertain about when structural change might have taken place.

\section{RESEARCH FINDINGS AND DISCUSSION}

The study employs annual time series data from; 1986-2017. The variables under study are real estate prices, remittances, exchange rates and inflation. Data on lending and mortgage rates are much desired but a credible and sizeable one for the period under study is not obtained. Exchange rate here is the official exchange rate expressed as Ghana Cedis per US Dollar. Inflation is the GDP deflator. Remittances and real estate prices are all expressed in Ghana Cedis. Table 4.1 shows the summary statistics of the variables.

Table 4.1: Descriptive Statistics

\begin{tabular}{l|cccc}
\hline & Real Estate Prices & Remittances & Exchange Rates & Inflation \\
\hline Mean & 102.3707 & $7.99 \mathrm{E}+08$ & 0.999782 & 21.92767 \\
Median & 42.05471 & 4897754. & 0.754361 & 17.30950 \\
Maximum & 573.6630 & $9.82 \mathrm{E}+09$ & 4.447000 & 59.46155 \\
Minimum & 0.158310 & 32399.99 & 0.009000 & 8.726837 \\
Std. Dev. & 151.1563 & $2.57 \mathrm{E}+09$ & 1.207249 & 12.41686 \\
Observations & 32 & 32 & 32 & 32 \\
\hline
\end{tabular}

Source: Estimated by the authors using E-views 6.0 
All four variables have positive kurtosis. In other words, they are Leptokurtic or peaked. Higher values are above their means. The degree of asymmetry measured by skewness also indicates that all four variables are positively skewed with long right tail implying higher values above the sample average. Before the unit root test, observation of the evolution of the various variables is made on Figure 4.1. Inspecting the evolution on Figure 4.1, real estate prices and remittances have been rising over the years. There seem to be a little spark in remittances in year 2015. Exchange rates, Ghana cedi per US dollar is constantly depreciating. Inflation in Ghana is volatile and looks to be better down the years.

Figure 4.1: Evolution of Real Estate Prices, Remittances, Exchange Rates and Inflation

Real Estate Prices

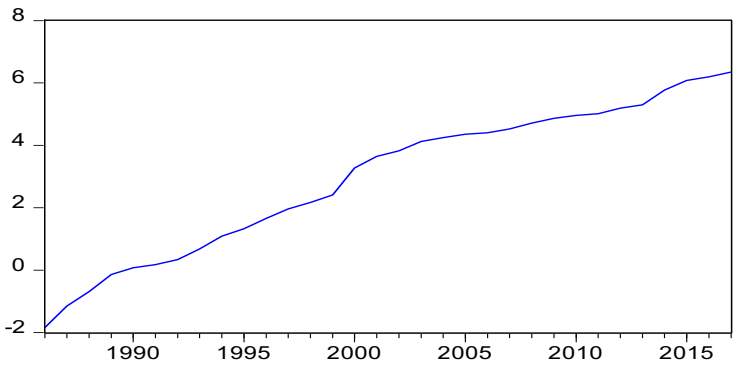

Inflation

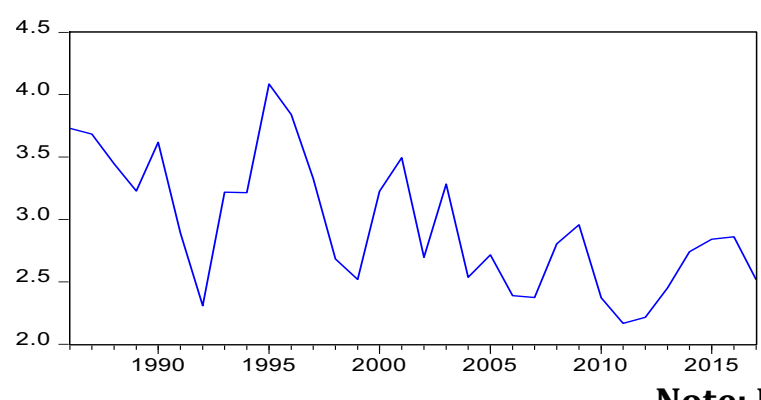

REMITTANCES

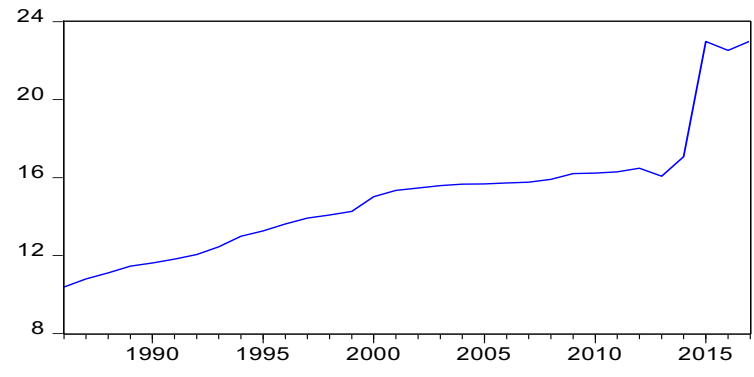

Exchange Rates

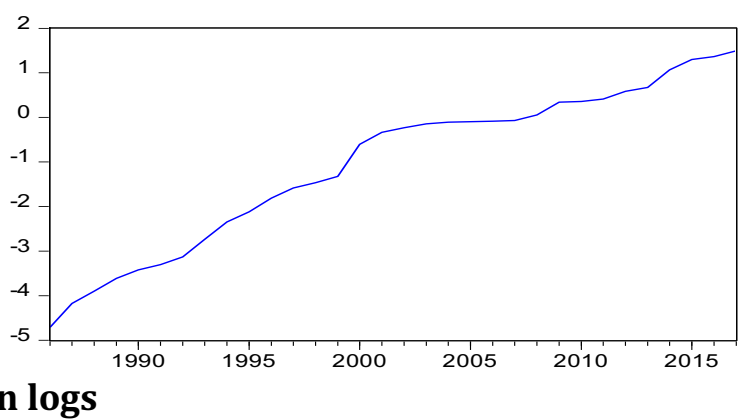

\section{Unit Root Tests}

The empirical model for estimation, ARDL bounds testing of cointegration strictly require that a data series be either I(0) or I(1). This is because a stochastic trend of I(2) will crash the F statistic used to determine the long run relationship among the variables. Before the unit root test, each variable is transformed into natural. Augmented Dickey Fuller (ADF) and PhillipPerron unit root tests are implemented to assess the stationarity of the variables. The results are reported in table 4.2 .

Except real estate prices (lnrepx), both ADF and PP could not reject the null hypothesis of unit root for all other variables in levels. After first differencing however, unit root is rejected for inflation $(\ln i n f)$, official real exchange rate (lnexr) and remittances (lnremit). Thus real estate price is I $(0)$ and the rest of the variables are I(1). The real estate price is sourced directly from the sector industry. It is suggested that, data from such sources are often I(0). 
Table 4.2: Results of the Unit Root Tests in Levels and First Difference

\begin{tabular}{|c|c|c|c|c|c|c|c|}
\hline \multirow[t]{2}{*}{ Variable } & \multirow[t]{2}{*}{ Tests } & \multicolumn{3}{|l|}{ LEVELS } & \multicolumn{3}{|c|}{ FIRST DIFFERENCE } \\
\hline & & T statistic & P Values & Conclusion & t Statistic & P Values & Conclusion \\
\hline \multirow[t]{2}{*}{$\ln r e p x$} & $\mathrm{ADF}$ & -3.043861 & 0.0418 & Stationary & & & \\
\hline & $\mathrm{PP}$ & -3.043861 & 0.0418 & Stationary & & & \\
\hline \multirow[t]{2}{*}{ lnremit } & $\mathrm{ADF}$ & 0.294078 & 0.9742 & Unit root & -5.413149 & 0.0001 & Stationary \\
\hline & $\mathrm{PP}$ & 0.564856 & 0.9863 & Unit root & -5.414959 & 0.0001 & Stationary \\
\hline \multirow[t]{2}{*}{ lnexr } & $\mathrm{ADF}$ & -2.770339 & 0.0742 & Unit root & -4.289916 & 0.0021 & Stationary \\
\hline & $\mathrm{PP}$ & -2.587934 & 0.1062 & Unit root & -4.289916 & 0.0021 & Stationary \\
\hline \multirow[t]{2}{*}{$\operatorname{lninf}$} & $\mathrm{ADF}$ & -2.919996 & 0.0545 & Unit root & -5.010309 & 0.0004 & Stationary \\
\hline & PP & -2.717019 & 0.0826 & Unit root & -13.61021 & 0.0000 & Stationary \\
\hline
\end{tabular}

$\ln r e p x=$ real estate prices; lnremit = remittances; $\operatorname{lnexr}=$ exchange rate; and $\operatorname{lninf}=$ =Inflation Source: Estimated by the authors using E-views 6.0

In Figure 4.1, it was noted that there seem to be a break in the series from 1999 to 2017 for real estate prices and exchange rates, a break at year 2013 for remittances and 1997 for inflation. Further test was required to confirm the stationarity found now. Breakpoint unit root test were done. Results confirm that the real estate prices are indeed I(0) whereas remittances, exchange rates and inflation are I(1). Having I( 0$)$ and I(1) annual series running over 31 years, ARDL model of cointegration is the only model for the best outcome in this study.

Moreover, the seeming breaks identified in Figure 4.1 are not taken lightly. Chow breakpoint test are done before doing ARDL bounds testing. Reported in table 4.3, for all four variables, the tests fail to reject the null hypothesis of no breaks at the specified break points at 5\% significance. There is therefore no reason to include structural breaks in the ARDL model.

Table 4.3: Chow Breakpoint Test

\begin{tabular}{|c|c|c|c|c|c|c|}
\hline & & & $\ln r e p x$ & lnremit & lnrex & $\operatorname{lninf}$ \\
\hline F-statistic & 0.129862 & Prob. $F(1,29)$ & 0.4866 & 0.1268 & 0.5210 & 0.6244 \\
\hline Log likelihood ratio & 0.138508 & Prob. Chi-Square(1) & 0.4681 & 0.1113 & 0.5033 & 0.6096 \\
\hline Wald Statistic & 0.129862 & Prob. Chi-Square(1) & 0.4810 & 0.1160 & 0.5159 & 0.6207 \\
\hline
\end{tabular}

Break points tested: lnrepx:1999; lnremit: 2013; lnrexr 1999; lninf 1997

Source: Estimated by the authors using E-views 6.0

\section{Long run form and Bounds Test of Cointegration}

Bounds test of cointegration is used to investigate the existence of long-run equilibrium relationship between real estate prices, remittances, exchange rate and inflation. For the model to be reliable to tell the true short run and long run relationships, the bounds test must be free from autocorrelation and heteroskedasticity. Hence, several bounds tests are performed.

At this point, the study is concerned with a case where real estate price is the dependent variable. That notwithstanding, the study makes it extensive here a bit. With four variables, each is made to assume a dependent variable in turn. The rational is purely to ascertain that 
possible cointegration between these variables depends on the arrangement of the variables or the role each variable assume in an equation. In these equations, each variable is at a point in time expressed as a dependent variable on its lags and current and lagged values of the remaining three variables. Model selection is based on AIC. In each case the robust model selected is one that is stable with normally distributed errors and no serial correlation. Specifically, for real estate prices as dependent variable, what is estimated is equation 3.6 in chapter three. Summary result of the ARDL bounds test of cointegration is presented in Table 4.4 .

Table 4.4 ARDL Long run form and bounds test of cointegration

$\begin{array}{llllll}\begin{array}{l}\text { Dependent } \\ \text { Variable } \\ \text { Lnrepx }\end{array} & \begin{array}{l}\text { ARDL Model } \\ \text { Selection }\end{array} & \text { Test Statistic } & \text { I(0) } & \text { I(1) } & \text { Decision } \\ \text { ARDL(1,0,1,0) } & \text { F-Statistic }=2.243301 & 3.272 & 4.306 & \text { Inconclusive } \\ & \text { ARDL(1,2,0,0) } & \text { F-Statistic }=1.523893 & 3.71 & 5.018 & \text { No Cointegration } \\ & & \text { t-Statistic }=-1.070993 & -2.86 & -3.78 & \\ \text { Lnexr } & \text { ARDL(1,2,0,3) } & \text { F- Statistic }=1.878035 & 3.272 & 4.306 & \text { No Cointegration } \\ \text { Lninf } & \text { ARDL(1,1,0,0) } & \text { F- Statistic }=4.953267 & 3.164 & 4.194 & \text { Cointegration }\end{array}$

Null: No long run relationship; F-Statistics and t-Statistic and their critical values are at $5 \%$ significance.

\section{Source: Estimated by the authors using E-views 6.0}

From the table when exchange rate is the dependent, the F-Statistic is below the lower bound I(0), so there is no cointegration. Similar result occurred when remittances assumed the dependent. When inflation is considered a dependent variable, the F-Statistic is higher than the critical value at the upper bound I(1), rejecting the null of no long run relationship between the variables. Inflation is cointegrated with other variables. There is therefore a long run stable equilibrium relationship between the variables when inflation is the dependent. But there is no such relationship between the variables when either remittance or exchange rate is the dependent variable.

Since the primary concern of this study is to know the effects of exchange rate volatility on real estate prices, the major concern is on equation 3.6. In this equation real estate price is expressed on remittance, exchange rate and inflation. Bounds test of the equation is inconclusive. The F-statistic fall between the lower bound $I(0)$ and the upper bound I(1) at 5\% significance. The null of no long run relationship cannot be rejected or accepted with certainty. This required further investigation to establish clarity. Johansen test of cointegration is performed. It is often argued that Johansen cointegration is only adopted when all the variables are I(1). But According to Johansen and Juselius (1990), not all the individual variables investigated for cointegration need be I(1). So, some can be I(0) as it is the case with our real estate variable. In this regard Johansen test of cointegration is conducted with 3 lags. The test divulged the existence of cointegration equations between the variables. The details of the results can be found in the appendix 1 . The vector error correction model (VECM) estimate the error correction term to be $-\mathbf{0 . 8 3 3 7 5 7}$. As required this speed of adjustment is negative. It is 
also significant (p-values: 0.0109 ) at 1\%. Now it has been established that the real estate prices is cointegrated with remittances, exchange rates and inflation.

With this conclusion the study continues to investigate the long run and error correction model using ARDL approach since it is the best among the host of cointegration models when it comes to small samples.

\section{Long run and Error Correction Models}

As specified in equation 3.9, the long run specification models are a relationship between the variables without any short-run shock. In other words it is the relationship to which variables always return after deviating from it. Unlike the short run which is in first difference, the long run model is modeled in levels. Lag length is provided by information criteria. After estimating the long run model, the residuals are extracted. The residuals added to short run model but at lag 1 as the error correction term to form the error correction model. The error correction term, $E C T_{t-1}$ specifies the speed of adjustment to long run equilibrium following a shock in the previous year. It must be negative and significant

Table 4.5 reports the results for the long run relationship between real estate prices and the underlying variables. The lag length is three. It is identified that real estate prices do not respond to its lags in the long run. Remittances have significant negative causality on real estate prices at lag 1 and 3. The effects are 10\% significant at one year lag and 5\% significant at three year lag. Exchange rates have no significant relationship or causal effects on real estate prices. 
Table 4.5: Long run model and Error Correction Model of Real Estate Prices (REPX)

\begin{tabular}{|c|c|c|c|c|}
\hline Variable & Coefficient & Std. Error & t-Statistic & Prob. \\
\hline \multicolumn{5}{|l|}{ Long Run } \\
\hline $\mathrm{C}$ & -17.18 & 9.86 & -1.74 & 0.10 \\
\hline LNREPX(-1) & 0.49 & 0.48 & 1.02 & 0.32 \\
\hline LNREPX(-2) & -0.32 & 0.69 & -0.46 & 0.65 \\
\hline LNREPX(-3) & -0.15 & 0.40 & -0.36 & 0.72 \\
\hline LNREMIT(-1) & 0.16 & 0.08 & 2.04 & $0.06^{*}$ \\
\hline LNREMIT(-2) & -0.11 & 0.07 & -1.61 & 0.13 \\
\hline LNREMIT(-3) & 1.40 & 0.65 & 2.16 & $0.05^{* *}$ \\
\hline $\operatorname{LNEXR}(-1)$ & 0.06 & 0.55 & 0.12 & 0.91 \\
\hline $\operatorname{LNEXR}(-2)$ & 0.57 & 0.77 & 0.74 & 0.47 \\
\hline $\operatorname{LNEXR}(-3)$ & -1.21 & 0.78 & -1.54 & 0.14 \\
\hline $\operatorname{LNINF}(-1)$ & -0.07 & 0.09 & -0.73 & 0.48 \\
\hline $\operatorname{LNINF}(-2)$ & -0.21 & 0.09 & -2.27 & $0.04^{* *}$ \\
\hline $\operatorname{LNINF}(-3)$ & -0.12 & 0.11 & -1.13 & 0.27 \\
\hline \multicolumn{5}{|l|}{ Error Correction } \\
\hline $\mathrm{C}$ & -0.02 & 0.08 & -0.23 & 0.82 \\
\hline$\Delta($ LNREPX $(-1))$ & 0.51 & 0.43 & 1.18 & 0.26 \\
\hline$\Delta($ LNREPX $(-2))$ & -0.28 & 0.44 & -0.63 & 0.54 \\
\hline$\Delta($ LNREPX $(-3))$ & -0.22 & 0.37 & -0.60 & 0.56 \\
\hline$\Delta($ LNREMIT $(-1))$ & 0.17 & 0.07 & 2.27 & $0.04^{* *}$ \\
\hline$\Delta($ LNREMIT $(-2))$ & -0.11 & 0.06 & -1.81 & 0.09 \\
\hline$\Delta($ LNREMIT $(-3))$ & 1.35 & 0.64 & 2.12 & $0.05^{* *}$ \\
\hline$\Delta(\operatorname{LNEXR}(-1))$ & 0.25 & 0.49 & 0.52 & 0.61 \\
\hline$\Delta(\operatorname{LNEXR}(-2))$ & 0.23 & 0.50 & 0.45 & 0.66 \\
\hline$\Delta(\operatorname{LNEXR}(-3))$ & -0.89 & 0.81 & -1.10 & 0.29 \\
\hline$\Delta(\operatorname{LNINF}(-1))$ & -0.04 & 0.08 & -0.56 & 0.58 \\
\hline$\Delta(\operatorname{LNINF}(-2))$ & -0.16 & 0.07 & -2.17 & $0.05^{* *}$ \\
\hline$\Delta(\operatorname{LNINF}(-3))$ & -0.05 & 0.08 & -0.57 & 0.58 \\
\hline ECT $(-1)$ & -1.40 & 0.41 & -3.39 & $0.00^{* * *}$ \\
\hline
\end{tabular}

P- values:*** 1\%; ** 5\%; * 10\% significance; R-squared: 0.997155 ; Adjusted RSquared: 0.995021; F-Statistic: 467.3235; Prob(F-Statistic): 0.00000

\section{Source: Estimated by the authors using E-views 6.0}

Inflation has negative relationship with real estate prices. The causal negative relationship is $5 \%$ significant only for the 2 years lag. The R-Squared is 0.997155 , saying that $99.7 \%$ of real estate prices are explained by the explanatory variables.

The error correction model reveals the stability of this long run equilibrium relationship. Specifically, how 'a long run' equilibrium is restored after a deviation originating from short run dynamics. The result of the model specified in equation 3.7 is presented on Table 4.5. The error correction term (ECT(-1)) is -1.400897. It has the right negative sign and of $1 \%$ significance. Technically, the speed of adjustment to long run equilibrium is $140 \%$ after a deviation due to short run dynamics. $140 \%$ of deviations in the previous period are corrected. Note also that the short run dynamics are coming from remittance and inflation and are 5\% 
significant. Exchange rates and past real estate prices do not have short run dynamical impact on real estate prices. Such as found in the long run estimation. Just as found in long run estimation, inflation has negative and remittances have positive causal relationship with real estate prices. Exchange rates and past prices of real estate prices also follow the same tangent. Per this result consistency exist between the long run and error correction models.

\section{Diagnostic Checks}

Diagnostic checks are conducted in order to be confident about the findings or know which result to uphold. Very critical to the ARDL model of cointegration is the issue of autocorrelation. For the long run model, Breusch-Godfrey Serial Correlation LM test do not reject the null of no serial correlation. Additional test also indicates the model is homoskedastic and errors are normally distributed. Wald test jointly test the coefficients. The result rejects the null hypothesis, meaning that the coefficients are not the same and are significantly different from zero. Wald test is also conducted separately on the coefficient of each of the explanatory variables. The coefficients of remittances are significantly different from zero. The same is said of inflation. The coefficients of exchange rate and past real estate prices are no different from zero.

Table 4.6 Diagnostic Checks for Long run and Error Correction models

\begin{tabular}{|c|c|c|c|}
\hline \multicolumn{4}{|c|}{$\begin{array}{l}\text { Long Run } \\
\text { Breusch-Godfrey Serial Correlation LM Test: }\end{array}$} \\
\hline F-statistic & 2.74 & Prob. $F(3,13)$ & 0.09 \\
\hline \multicolumn{4}{|c|}{ Heteroskedasticity Test: Breusch-Pagan-Godfrey } \\
\hline F-statistic & 1.22 & Prob. $F(12,16)$ & 0.35 \\
\hline $\begin{array}{l}\text { Test of Norme } \\
\text { Jarque - Bera: }\end{array}$ & 2.31 & Probability: & 0.32 \\
\hline $\begin{array}{l}\text { Wald Test } \\
\text { F-Statistic }\end{array}$ & 13.78 & Probability: & 0.00 \\
\hline
\end{tabular}

Source: Estimated by the authors using E-views 6.0

Figure 4.2: Test of Stability (CUSUM) ( Long run Model)

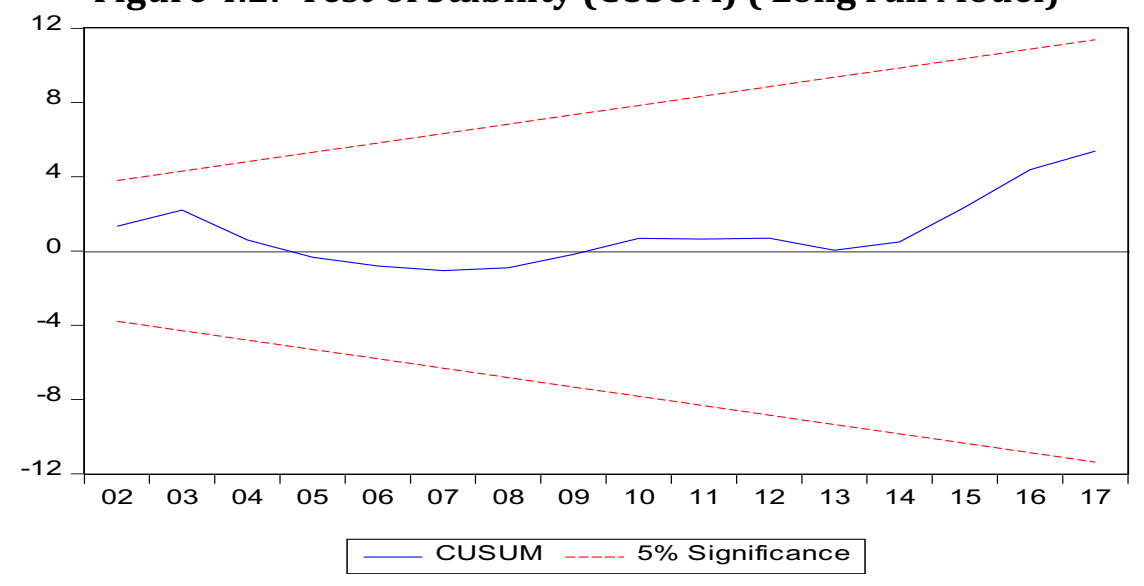

A good model must be stable. Stability test is conducted. Figure 4.2 is the output of the recursive estimate using CUSUM. The long run model perfectly lies between the $5 \%$ confidence.

The error correction model is also diagnosed. Breusch-Godfrey Serial Correlation LM test shown on Table 4.8 fails to reject the null of no serial correlation. The model is homoskedastic 
and errors are very near normal distribution. Wald test reject the null hypothesis. Jointly, the coefficients are significantly different from zero. The coefficients of remittances are significantly different from zero. The same is said of inflation. The coefficients of exchange rate and past real estate prices are no different from zero. CUSUM tells the model is stable.

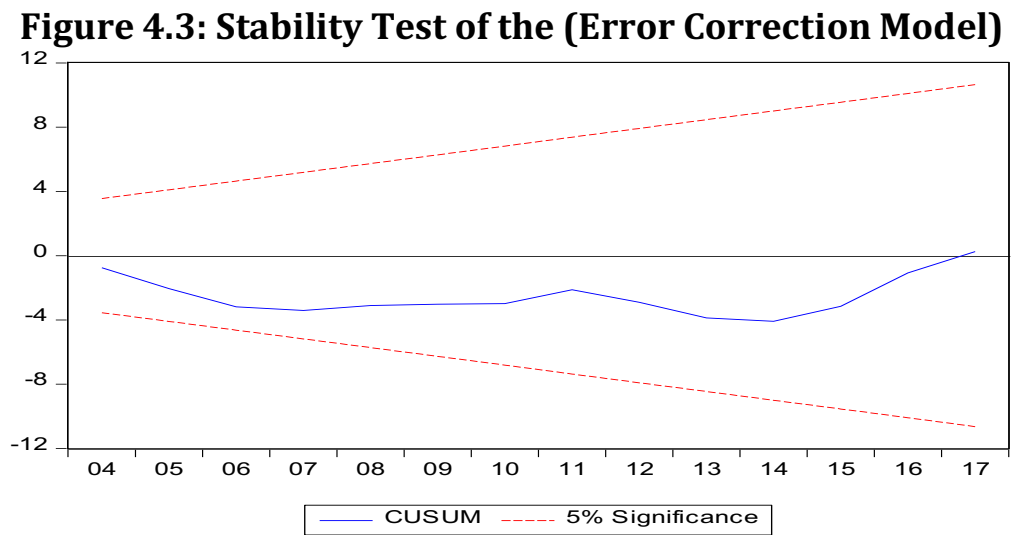

At this moment the study is confident to say that real estate price is cointegrated with remittance, exchange rate and inflation. The long run equilibrium is stable and significant. Exchange rates do not cause changes in real estate prices in long run. Similarly past prices of real estate do not have impact on current house prices. Rather, remittances positively influence real estate prices. Inflation has a negative impact on real estate prices. Any deviation in the long run equilibrium will come from the short run dynamical impact of remittance and inflation. Such shocks will be corrected at a speed of $140 \%$.

Increase in remittances increases the disposable income of households. Individuals who are not able to rent their own apartment may obtain financial assistance in the form of remittance from relatives and friends residing abroad. This will exert demand forces on the real estate market leading to a rise in house price. This is most likely the case in that greater proportion of remittance coming to Ghana goes to household consumption. Another possibility is that Ghanaians residing abroad or foreigners living in Ghana may remit money into the country to purchase real estate properties. When this happens, demand for real estate properties will go up eventually causing real estate prices to increase. This view can be upheld given the rate of foreigners resident in the country, competing with middle income earners for accommodation.

The opposing argument which does not obtain support from the findings could be the idea that remittance increase household income and thereby increases their savings and investment rates. Houses being a major investment concern of households will therefore attract investment when remittances increase. When people put their homes demand pressures on the real estate market it will ease leading to a fall house prices.

Concerning inflation and real estate prices, as dynamic and endogenous as macroeconomic variables are, a negative relationship is highly practical. Central Banks target inflation using monetary policy. When inflation rates rise, to ease inflationary pressures, the Central Bank will increase its monetary policy rates. This will lead to increase in interest rates on money market and debts instruments such as T-Bills, Bonds and Fixed Deposits. By reducing money supply through interest rates, demand for mortgage or housing will fall. Real estate price will fall as response to a fall in demand for housing. Hence there exist negative relationships between inflation and real estate prices. 
The opposing argument may be that in the presence of high inflation, households will find physical asset like house as a store of value. So demand for housing will increase for real estate prices to rise. Besides that, inflation itself is the persistence increase in prices of goods and services. An increase in inflation could rightly mean increase in prices of building materials, raising the cost to build and finally increasing prices of real estate.

\section{CONCLUSION AND RECOMMENDATIONS}

The study, based on the research objectives, shows clearly that fluctuations in the exchange rate has no effect or impact on residential real estate houses which supports the findings of Diala, Kalu and Igwe-Kalu (2016). Clearly, the study shows that remittances and inflation have a direct impact on prices of residential houses. It is, therefore, concluded that, exchange rate volatility has no effect on real estate housing prices and also, past prices of real estate do not have impact on current house prices. Since the study finds that remittances positively cause real estate prices in the short and long run, and in essence, an increase in remittances raises real estate prices, which is detrimental to the Ghanaian real estate market and the efforts by governments to reduce housing deficits with the caption, affordable housing projects, arguably requires measures to reduce the flow of remittances. However, for developmental purposes, remittances have to increase to augment the local mobilization of funds. It is upon this dilemma that the impact of the flow of remittances on housing prices needs further and or future studies.

Again, the study finds that a rise in inflation negatively impacts the price of real estate houses. This is an indication that a rise in inflation decreases housing prices which has both positive and detrimental effects. Although, it is the quest of every Ghanaian to have house prices reduced for many people to be able to acquire, none would also want to experience rise in inflation. It is therefore recommended that the monetary policy makers should look at their control mechanisms with the real estate house prices in mind. They can mitigate the real estate house prices by prescribing some tax exemptions on imports of some building materials whilst they vigorously pursue their control of inflation.

\section{References}

Adewuyi, A. O., and Akpokodje, G., (2013). Exchange Rate Volatility and Economic Activities of Africa's SubGroups, The International Trade Journal

Alagidede, P. and Ibrahim, M. (2016) “The Causes and Effects of Exchange Rate Volatility on Economic Growth. Evidence from Ghana

Anim-Odame, W. K., Key,T. and Stevenson, S. (2010a): Residential Market Development in Sub-Saharan Africa. International Journal for Housing Market and Analysis 3, (4)

Anim-Odame, W. K., Key,T. and Stevenson, S. (2010b): The Ghanaian Transaction-based Residential Indices. International Journal for Housing Market and Analysis 3, (3)

Anim-Odame, W., Key, T. and Stevenson, S. (2009). Measures of Real Estate Values from Land Registration and Valuation Systems in Emerging Economies: the case of Ghana. Journal of Real Estate Literature

Attela, V, Atzeni E.G and Belvisi, P (2003), Investment and exchange rate under uncertainty, center for international studies on economic growth research paper series, vol 11,No.32 Avebury.

Bahmani-Oskooee, M. \& Kandil, M. (2007): Exchange Rate Fluctuations and Output in Oil Producing Countries: The Case of Iran. International Monetary Fund, IMF Working Paper, WP/07/113, 132

Bahmani-Oskooee, M. \& Nasir, A. B. M. (2004), ARDL approach to test the productivity bias hypothesis. Review of Development Economics, 8(3)

Bahmani-Oskooee, M., \& Gelan, A. (2018), “Exchange-rate volatility and international trade performance: Evidence from 12 African countries", Economic Analysis and Policy

Balaban, S. (2011) Migrant Remittances and Resulting Transformations of the Housing Market in Romania, Master's Thesis 
Buckley, R. M. and Mathema, A. S. (2007) Is Accra a Superstar City? The World Bank

CHF International (2004) Strategic Assessment of the affordable housing sector in Ghana

Clark, P., Tamirisa, N., and Wei, S-J., (2004). A New Look at Exchange Rate Volatility and Trade Flows, IMF Occasional Paper

Danjuma, B. F., Shuaibu, U., and Sa'id, U. Y., (2013). An Assessment of Exchange Rate Volatility and Inflation in Nigeria. Journal of Emerging Issues in Economics, Finance and Banking (JEIEFB)

Dell'Ariccia, G., (1999). "Exchange Rate Fluctuations and Trade Flows: Evidence from The European Union", IMF Stuff Paper

Diala A. O., Kalu I. U. \& Igwe-Kalu A. (2016), Effects of exchange rate volatility on commercial property returns in Nigeria. African Journal of Accounting, Economics, Finance and Banking Research, Vol. 10 No. 10

Dickey, D. A., and Fuller, W. A. (1979) Distribution of Estimators for Autocorrelated, Time Series with a Unit Root Journal of the American Statistical Association

Dickey, D. A., and W. A. Fuller (1981) Likelihood Ratio Test for Autoregressive Time Series with a Unit Root. Econometrica 49, 1057-72.

Eichengreen, B., (2008) The Real Exchange Rate and Economic Growth, Commission on Growth and Development Working Paper No. 4.

Fayissa, B. and Nsiah, C. (2008) The Impact of Remittances on Economic Growth and Development in Africa. Department of Economics and Finance Working Paper Series

Fiadzo, E. (2004) Estimating the Determinants of Housing Quality: the Case of Ghana. Joint Centre for housing studies, working paper series

Fuller, W.A. (1996). Introduction to Statistical Time Series, New York: John Wiley and Sons Publishing Ltd.

Fuentes, O. M., (2006). Exchange Rate Volatility and Investment: Evidence at the Plant-Level. Boston University, mimeo

Ghana Statistical Service (2005) Population Data Analysis Report,

Ghatak S. and Siddiki, J.(2001), The use of ARDL approach in estimating virtual exchange rates in india, journal of applied statistics

Grydaki, M. and Fountas, S., (2009) Exchange Rate Volatility and Output Volatility: A Theoretical Approach. Review of International Economics, 17 (3)

Hammond, F. (2006) Real estate resource control: policy incentives and investment for development. RICS Research Paper Series Vol. 6 No. 11

Johansen, S. and Juselius, K., (1990) Maximum Likelihood Estimation and Inference on Cointegration with Application to the Demand for Money, Oxford Bulletin of Economics and Statistics

Johansen, S. and Juselius, K., (1999) "Maximum Likelihood Estimation and Interference on Cointegration with Applications to the Demand for Money", Oxford Bulletin of Statistics,

Jorion, P (1990), The exchange rate exposure of US multinationals, Journal of Business

Joseph, A. I. and Akhanolu, I (2011), An empirical investigation of the link between exchange rate volatility and trade in Nigeria, Journal of Emerging Trends in Economics and Management Sciences

Kiyota K. and Urata, S. (2004) Exchange Rate Volatility and Foreign Direct Investment, World Economy

Land Title Registration Law, (PNDCL 152) 1986

Lee, S. L and Thomas, M (2006), Impact of exchange rates on international Real Estate portfolio, Journal of Real Estate Portfolio management

Liu, C. H and Mei, J (1998); The predictability of international Real Estate markets, exchange rate risk and diversification consequences, Real Estate Economic,

Lim, G. and Tsiaplias, S., (2016) "Non-Linearity in the Relationship between House Prices and Interest Rates: Implications for Monetary Policy," 
Loyford, M. M. \& Moronge, M. (2014).Effects of economic factors on performance of real estate in Kenya, European Journal of Business Management

McKenzie, Michael D., (1999), “The Impact of Exchange Rate Volatility on International Trade Flows," Journal of Economic Surveys, Vol. 13, No. 1,

Mordi, C.N.O (2006), Challenges of exchange rate volatility in economic management in Nigeria. CBN bulletin $30(3)$

Murinde, V. (1993) Macroeconomic Policy Modelling for Developing Countries, Aldershot:

Obstfeld, M. and Rogoff, K.(1995); “Exchange rate dynamics redux” Journal of Political Economy,

Obstfeld, M. and Rogoff, K.(2000); “New Directions for Stochastic Open Economy Models,"Journal of International Economics

Olowe, R. (2009), Modeling naira / dollar exchange rate volatility: application of GARCH and asymmetric models, International Review of Business Research papers 5(3).

Omjimite, B.U. and Akpokodje, G. (2010). The Effect of Exchange Rates Volatility on the Imports of ECOWAS Countries. Journal of Social Sciences, 4 (2)

Omolara, A.C (2010), Foreign exchange market and monetary management in Nigeria, Journal of Emerging Trends in Economics and Management sciences

Osei-Assibey, K.P., 2010, Exchange rate volatility in LDCs: Some findings from the Ghanaian, Mozambican and Tanzanian markets. PhD Thesis, Submitted to Economics Studies Department, Collage of Arts and Social Science, University of Dundee, Country

Pesaran, M. H. \& Pesaran, B. (1997);Working with Microfit 4.0: An interactive approach. Oxford, Oxford University Press.

Pesaran, M. H. \& Shin, Y. (1999); Long-run structural modeling, Econometric Reviews

Pesaran, M. H., Shin, Y., \& Smith, R. J. (2001); Bounds testing approaches to the analysis of level relationships. Journal of Applied Economics

Phillips, P.C., \& Perron, P. (1988); Testing for a unit root in time series regression, Biometrika, Policy Research Working Paper

Saunders, M., Lewis, P. and Thornhill, A. (2007) Research Methods for Business Students Published by Pearson Education Limited

Senadza, B. and Diaba, D.D. (2017) Effect of Exchange Rate Volatility on Trade in Sub-Saharan Africa. Journal of African Trade

Tang, T. C. (2006). Are imports and exports of OIC member countries cointegrated? A re-examination; Journal of Economics and Management14(1),

Wang, Yajie and Wang, C. (2013), "Analysis of the Fundamentals to Influence the Price of China's Real Estate",

Webb, B and O'Keefe, J (2002), The case for global Real Estate. Working paper published by Global Asset Management

World Bank's World Development Indicators, accessed February, 2018. 